\title{
Prediction of Gas Chromatographic Retention Indices of Coumarins
}

\author{
Míriam de Freitas Soares ${ }^{\mathrm{a}}$, Franco Delle Monache ${ }^{\mathrm{b}}$, \\ Vilma Edite Fonseca Heinzen ${ }^{\mathrm{a}^{*}}$, and Rosendo A. Yunes ${ }^{\mathrm{b}}$ \\ ${ }^{a}$ Laboratório de Estrutura-Atividade, Departamento de Química, CFM, \\ Universidade Federal de Santa Catarina, 88040-900 Florianópolis - SC, Brazil \\ ${ }^{\mathrm{b}}$ Instituto di Chimica Recettori Molecole Biologicamente Attive del C.N.R., \\ Università Cattolica S. Cuore, Largo F. Vito 1,00168 Rome, Italy
}

O estudo de correlação entre estrutura-retenção (QSRR) foi usado para relacionar a retenção cromatográfica de diferentes cumarinas substituídas as suas características estruturais.

Diferentes parâmetros estruturais foram selecionados tais como: descritores topológicos, geométricos, eletrônicos, químico-quânticos e físico-químicos para encontrar uma equação que melhor explique o comportamento cromatográfico destes compostos.

O método proposto por Dimov que classifica os descritores em diferentes grupos de acordo com seus valores de coeficientes de correlação foi utilizado neste estudo.

As melhores equações de correlação linear múltipla foram obtidas com os seguintes descritores: área total $\left(\mathrm{A}_{\mathrm{T}}\right)$, índice do estado eletrotopológico (S-O-) e orbital molecular ocupado de maior energia (EHOMO), mostrando que a retenção experimental, usando fase estacionária de baixa polaridade está relacionada principalmente com fatores relacionados a forma e também eletrônicos.

Os modelos selecionados apresentaram uma boa predictabilidade, a qual foi estabelecida através dos valores do coeficiente de correlação de validação cruzada $\left(\mathrm{r}^{2} \mathrm{cv}\right)$. As equações encontradas podem ser utilizadas para auxiliar na elucidação da estrutura ou retenção cromatográfica de cumarinas similares às estudadas.

Quantitative structure-retention relationships (QSRR) were used in this study to relate the chromatographic retention of different substituted coumarins to molecular structure. Different structural parameters were selected, such as topological, geometric, electronic, quantum-chemical and physico-chemical descriptors, in order to find an equation that fitted the chromatographic retention of these compounds.

The method proposed by Dimov that classifies the descriptors in different groups in agreement with their values of correlation coefficients was analysed.

Significant correlation equations were obtained with the following molecular descriptors: the total surface area $\left(\mathrm{AT}_{\mathrm{T}}\right)$, the electrotopological state index $\left(\mathrm{S}_{(-\mathrm{o}-)}\right)$ of the oxygen in position 1 of coumarin, and the highest occupied molecular orbital energy (Еномо), showing that the experimental retention, using stationary phases with low polarity, was related with the shape and electronic factors of the solutes.

The models found have a good predictive ability as established by cross-validation $\mathrm{r}_{\mathrm{cv}}^{2}$ values and thus, can be used to aid in the elucidation of the structure or the chromatographic retention of similar coumarins.

Keywords: QSRR, retention indices, coumarins, molecular descriptors, multiple linear regression

\section{Introduction}

The quantitative structure-retention relationships $(\mathrm{QSRR})^{1}$, establishes the relationship between a chemical structure and its chromatographic retention value. The chromatographic retention is due to the integral effect of molecular interactions between the analyte and both mobile and stationary phase molecules. To define the structural descriptors best related to the characteristic of a particular 
solute to undergo both polar and dispersive interactions is an important step to understanding the process of chromatographic separation.

Using the QSRR approach, structural descriptors such as topological, geometric and electronic or physico-chemical descriptors can be proposed for molecules with similar structural features, and a subset of them can be selected in order to describe and predict the gas chromatographic retention indices ${ }^{2}$. Numerous authors have attempted to correlate and predict retention indices of a variety of compounds by use of molecular structural information or physico-chemical and quantum-chemical parameters ${ }^{3-20}$.

In this study, our aim was to select the best descriptors related to the chromatographic retention of different substituted coumarins (some of them are interesting natural products) using the QSRR, to broaden the approach of Dimov et al. ${ }^{3,4}$ which takes into account only hydrocarbons (alkylbenzenes, alkylnaphthalenes, isoalkanes and alkenes).

Dimov et al. ${ }^{3,4}$ suggested that the descriptors should be divided in groups according to correlation coefficient values for the simple linear regression. After this, the descriptors of different groups would be related through multiple regression to obtain the best equations. These equations would be formed by two groups of descriptors: basic and tuning. The basic descriptors are those that permit the calculation of the retention index values closest to the experimental values. The tuning descriptors are those that further tune the calculated value to experimental ones.

\section{Experimental}

\section{Samples and standards}

The different coumarins studied were obtained by extraction in the Instituto di Chimica Recettori Molecole Biologicamente Attive del C.N.R., Università Cattolica S. Cuore. The 6-methylcoumarin, 7-methylcoumarin, 4-hydroxycoumarin, coumarin and 3,4-dihydrocoumarin were obtained commercially from the Aldrich Chemical Company Inc. The analytical standards of hydrocarbons (n-alcanes, $\mathrm{nC}_{12}$ to $\mathrm{nC}_{22}$ ) were supplied by Aldrich Chemical Company Inc.

\section{Method of chromatographic analysis}

The gas chromatographic retention data for 20 substituted coumarins chromatographed on two stationary phases with low polarities are indicated in Table 1. The sample solutions were prepared with acetone, and to some of them

Table 1. Experimental retention indices on the CBP5 (RICBP5) and LM-1 (RILM-1) stationary phases at $170^{\circ} \mathrm{C}, 190^{\circ} \mathrm{C}$ and $210^{\circ} \mathrm{C}$ for the coumarin series.

\begin{tabular}{|c|c|c|c|c|c|c|c|}
\hline No. & Compound & $\begin{array}{c}\mathrm{RI}_{\mathrm{CBP} 5} \\
\left(170^{\circ} \mathrm{C}\right)\end{array}$ & $\begin{array}{c}\mathrm{RI}_{\mathrm{CBP} 5} \\
\left(190^{\circ} \mathrm{C}\right)\end{array}$ & $\begin{array}{c}\mathrm{RI}_{\mathrm{CBP} 5} \\
\left(210^{\circ} \mathrm{C}\right) \\
\end{array}$ & $\begin{array}{l}\mathrm{RI}_{\mathrm{LM}-1} \\
\left(170^{\circ} \mathrm{C}\right)\end{array}$ & $\begin{array}{c}\mathrm{RI}_{\mathrm{LM}-1} \\
\left(190^{\circ} \mathrm{C}\right) \\
\end{array}$ & $\begin{array}{l}\mathrm{RI}_{\mathrm{LM}-1} \\
\left(210^{\circ} \mathrm{C}\right)\end{array}$ \\
\hline 1 & Coumarin & 1492 & 1510 & 1533 & 1434 & 1458 & 1472 \\
\hline 2 & 3,4-Dihydrocoumarin & 1451 & 1473 & 1494 & 1398 & 1422 & 1430 \\
\hline 3 & 6-Methylcoumarin & 1588 & 1607 & 1631 & 1545 & 1564 & 1574 \\
\hline 4 & 7-Methylcoumarin & 1586 & 1607 & 1630 & 1545 & 1562 & 1574 \\
\hline 5 & 6-Methoxycoumarin & 1835 & 1850 & 1867 & 1762 & 1776 & 1780 \\
\hline 6 & 7-Ethoxycoumarin & 1815 & 1829 & 1846 & 1754 & 1771 & 1779 \\
\hline 7 & 4-Hydroxycoumarin & 1740 & 1739 & 1733 & 1656 & 1665 & 1652 \\
\hline 8 & 6-Hydroxycoumarin & 1840 & 1849 & 1864 & 1760 & 1771 & 1770 \\
\hline 9 & 7-Hydroxycoumarin & 1866 & 1875 & 1886 & 1789 & 1797 & 1795 \\
\hline 10 & 6-Acetocoumarin & 1846 & 1853 & 1869 & 1768 & 1784 & 1790 \\
\hline 11 & 7-Acetocoumarin & 1851 & 1864 & 1881 & 1779 & 1796 & 1803 \\
\hline 12 & 6-Aminocoumarin & 1872 & 1880 & 1917 & 1784 & 1806 & 1816 \\
\hline 13 & 6-Chlorocoumarin & 1639 & 1652 & 1675 & 1578 & 1599 & 1607 \\
\hline 14 & 7-Chlorocoumarin & 1643 & 1657 & 1677 & 1586 & 1608 & 1616 \\
\hline 15 & 6-Iodocoumarin & 1859 & 1879 & 1906 & 1780 & 1805 & 1818 \\
\hline 16 & 6-Nitrocoumarin & 1875 & 1889 & 1912 & 1775 & 1795 & 1805 \\
\hline 17 & 7-Nitrocoumarin & 1877 & 1894 & 1913 & 1784 & 1809 & 1821 \\
\hline 18 & 6-Formaldehydecoumarin & 1759 & 1770 & 1788 & 1673 & 1693 & 1701 \\
\hline 19 & 6-Carboxycoumarin & 1942 & 1949 & 1962 & 1858 & 1871 & 1870 \\
\hline 20 & 6-Cyanocoumarin & 1638 & 1651 & 1674 & 1579 & 1599 & 1608 \\
\hline
\end{tabular}


methanol was added. Samples of $1 \mu \mathrm{L}$ were injected into a gas chromatograph Shimadzu (Model GC-14A) equipped with a flame ionisation detector, connected to a recorder (Shimadzu Model C-R6A). The carrier gas was hydrogen at a flow-rate of $2.0 \mathrm{~mL} \mathrm{~min}{ }^{-1}$ in all instances. Two fused silica capillary columns of LM $1 \mathrm{n}_{\mathrm{o}} .360696$ (L\&M São Carlos, SP, Brazil) a polydimethylsiloxane liquid phase with $0.25 \mathrm{~mm}$ i.d. and of CBP5 PN 221-28636-25 (Shimadzu Co., Kyoto, Japan) a polydimethylphenylsiloxane $5 \%$ phenyl, bonded liquid phase with $0.22 \mathrm{~mm}$ i.d. were utilised. Both the columns were $25 \mathrm{~m}$ long and with 0.25 $\mu \mathrm{m}$ film thickness. The injector and detector temperatures were $250{ }^{\circ} \mathrm{C}$ and $280{ }^{\circ} \mathrm{C}$, respectively. The retention times were measured at different isothermal column temperatures: $170{ }^{\circ} \mathrm{C}, 190{ }^{\circ} \mathrm{C}, 210{ }^{\circ} \mathrm{C}, 220^{\circ} \mathrm{C}$ and $230{ }^{\circ} \mathrm{C}$. The experimental retention time $\left(\mathrm{t}_{\mathrm{R}}\right)$ was obtained using the average of three experimental determinations. The standard deviations are less than $0.01 \%$.

The dead time $\left(\mathrm{t}_{\mathrm{M}}\right)$ was determined by the Method of Sharles and Vermon $^{21}$. The measurements were always taken before each determination of the retention time.

The Kovàts retention indices were determined through the adjusted retention times $\left(t_{R}-t_{M}\right)$, according to the equation of Kovàts ${ }^{22}$, using n-alcanes as standards.

\section{Method of calculation of molecular descriptors}

The structural descriptors used in the present study were topological and quantum-chemical indices and physicochemical properties.

Several extensive reviews have been published which give detailed descriptions of the theory and method of calculation of all topological indices used in the present investigation $^{23-28}$.

The Wiener indices $(\mathrm{W})^{23}$, the molecular connectivity indices of different orders $\left({ }^{1} \mathrm{X},{ }^{2} \mathrm{X},{ }^{3} \mathrm{X}_{\mathrm{p}},{ }^{4} \mathrm{X}_{\mathrm{p}},{ }^{5} \mathrm{X}_{\mathrm{p}},{ }^{3} \mathrm{X}_{\mathrm{c}}\right.$, ${ }^{4} \mathrm{X}_{\mathrm{pc}},{ }^{1} \mathrm{X}^{\mathrm{v}},{ }^{2} \mathrm{X}^{\mathrm{v}},{ }^{3} \mathrm{X}_{\mathrm{p}}^{\mathrm{v}},{ }^{4} \mathrm{X}_{\mathrm{p}}^{\mathrm{v}},{ }^{5} \mathrm{X}_{\mathrm{p}}^{\mathrm{v}},{ }^{3} \mathrm{X}_{\mathrm{c}}^{\mathrm{v}}$ and ${ }^{4} \mathrm{X}_{\mathrm{pc}}^{\mathrm{v}}{ }^{24}$, indices of molecular shape, kappa values $\left({ }^{1} \mathrm{~K},{ }^{2} \mathrm{~K},{ }^{3} \mathrm{~K}\right){ }^{25}$, indices of electrotopological state $(\mathrm{Si})^{26,27}$ and topological state indices $\left(\mathrm{T}_{\mathrm{i}}\right)^{28}$, were calculated by the method of Kier and Hall, utilizing the Molconn-X computer program for molecular topological analysis ${ }^{29}$.

The topological state index $T_{i}$, of an atom, gives information on the topological environment of the atom according to the presence of the other atoms in the molecule. The values of $T_{i}=T_{(=0)}$, are related to the oxygen of the carbonyl in the basic structure of coumarins. $\mathrm{T}_{(-\mathrm{O}-)}$ indices are related to the oxygen of position 1 in the coumarin. They distinguish also all the compounds studied (see Table 2).

The electrotopological state index $\left(\mathrm{S}_{\mathrm{i}}\right)$ gives information about the electronic and topological state of an atom according to the presence of other atoms in the molecule. It was considered that $\mathrm{S}_{(-\mathrm{O}-)}$, related to the oxygen of position 1 in the coumarin molecule, distinguished all the compounds studied (Table 2).

The molecules were drawn using the PcModel version 3.01 computer program, and the figures were exported to be geometrically energy-minimised using the PM3 quantum mechanical method. Subsequently, the energy-optimised molecular structure was used for generating a number of molecule parameters utilising the semi-empirical molecular orbital Mopac program ${ }^{30}$.

The following quantum mechanical molecular properties were chosen for the study: the highest occupied molecular orbital energy $\left(\mathrm{E}_{\text {Номо }}\right)$, and the lowest unoccupied molecular orbital energy ( $\left.\mathrm{E}_{\text {LUMO }}\right)$. Other derived properties obtained were: the total surface area $\left(\mathrm{A}_{\mathrm{T}}\right)$, saturated area $\left(A_{S}\right)$, unsaturated area $\left(A_{U N S}\right)$, polar area $\left(A_{P}\right)$, molecular volume ( $\left.\mathrm{V}_{\text {MOLEC }}\right)$, molar volume ( $\left.\mathrm{V}_{\text {MOLAR }}\right)$, total energy $\left(\mathrm{E}_{\mathrm{T}}\right)$, molar refractivity $(\mathrm{RM})$. In addition, the following physical properties of the coumarins were also selected: molecular mass $\left(\mathrm{M}_{\mathrm{M}}\right)$ and boiling point $\left(\mathrm{T}_{\mathrm{b}}\right)$. Some of the values are given in Table 2 .

The best regression equations were selected on the basis of the multiple correlation coefficient (r), r-squared, standard deviation (SD), the overall $\mathrm{F}$ value and the F-remove for individual descriptors (F-to-remove: 4.00 ) in the stepwise selection. Finally, in order to estimate the predictive power of the model, cross-validation, following the leaveone-out scheme was performed ${ }^{32,33}$. The reliability of the model was tested in a cross-validation with determination of $r^{2}{ }_{\mathrm{cv}}{ }^{32}$.

All the calculations of single and multiple linear regression analyses were carried out using the Statgraf and Origin computer programs.

\section{Results and Discussion}

The basic structure of mono-substituted coumarins with the corresponding substituents studied are given below:<smiles>[R]c1cc2oc(=O)cc([R])c2cc1[R]</smiles>

$$
\begin{aligned}
\mathrm{R}_{4}= & -\mathrm{OH} ; \mathrm{R}_{7}=\mathrm{R}_{6}=\mathrm{H} \\
\mathrm{R}_{6}= & -\mathrm{OH} ;-\mathrm{COCH}_{3} ;-\mathrm{NO}_{2} ;-\mathrm{CHO} ;-\mathrm{OCH}_{3} ;-\mathrm{I} ; \\
& -\mathrm{NH}_{2} ;-\mathrm{Cl} ;-\mathrm{COOH} ;-\mathrm{CN} ; \mathrm{R}_{4}=\mathrm{R}_{7}=\mathrm{H} \\
\mathrm{R}_{7}= & -\mathrm{OH} ;-\mathrm{OCH}_{2} \mathrm{CH}_{3} ;-\mathrm{COCH}_{3} ;-\mathrm{Cl} ;-\mathrm{NO}_{2} ; \\
& \mathrm{R}_{4}=\mathrm{R}_{6}=\mathrm{H}
\end{aligned}
$$

The values of the chromatographic retention indices (RI) of different coumarins studied, using the stationary phases LM-1 (RI $\left.\mathrm{LM}_{\mathrm{LM}-1}\right)$ and $\mathrm{CBP} 5$ (RI $\mathrm{I}_{\mathrm{CBP}}$ ) at different isothermal temperatures of columns $170-210{ }^{\circ} \mathrm{C}$, are given in Table 1. 
Table 2. Molecular connectivity indices of $1^{\text {st }}$ and $2^{\text {nd }}$ orders $\left({ }^{1} \mathrm{X},{ }^{2} \mathrm{X}\right)$, Wiener indices $(\mathrm{W})$, Kappa index $\left({ }^{1} \mathrm{~K}\right)$, topological state indices $\left(\mathrm{T}_{\mathrm{i}}\right)$, electrotopological state indices $\left(\mathrm{S}_{\mathrm{i}}\right)$ for the oxygen of position-1 $\left(\mathrm{S}_{(-\mathrm{O}-)}, \mathrm{T}_{(-\mathrm{O}-)}\right)$ and for the oxygen of carbonyl in the lactone group $\left(\mathrm{S}_{(=0)}, \mathrm{T}_{(=0)}\right)$. Total surface area (АT), Polar area (AP), Molecular volume (VMolec), Total energy (ЕT), Energy of the highest occupied molecular orbital (EHOMO), for the coumarin series.

\begin{tabular}{|c|c|c|c|c|c|c|c|c|c|c|c|c|c|}
\hline No & ${ }^{1} \mathrm{X}$ & $\mathrm{x}$ & $\begin{array}{l}\mathrm{A}_{\mathrm{T}} \\
\left(\mathrm{A}^{2}\right)\end{array}$ & $\begin{array}{l}A_{P} \\
\left(A^{2}\right) \\
\end{array}$ & $\begin{array}{c}\mathrm{V}_{\text {MOLEC }} \\
\left(\mathrm{A}^{3}\right)\end{array}$ & $\begin{array}{c}\mathrm{E}_{\mathrm{T}} \\
(\mathrm{eV})\end{array}$ & $\begin{array}{c}\text { E }_{\text {HOMO }} \\
(\mathrm{eV})\end{array}$ & W & ${ }^{1} \mathrm{~K}$ & $\mathrm{~S}_{(-\mathrm{O}-)}$ & $S_{(=0)}$ & $\mathrm{T}(-\mathrm{o}-)$ & $\mathrm{T}_{(=\mathrm{O})}$ \\
\hline 1 & 5.3602 & 4.7228 & 154.66 & 32.443 & 172 & 745.2 & & 643 & & 060 & & 13.137 & 10.973 \\
\hline 2 & 3602 & .7228 & 161.58 & 2.304 & 182 & -1776.9 & -9.5136 & 643 & 6389 & 4.9929 & 0.803 & 2.884 & 10.748 \\
\hline 3 & 5.7540 & 5.3566 & 174.06 & 32.198 & 194 & -1895.0 & -9.3281 & 776 & 8.5917 & 4.9611 & 10.802 & 13.403 & 11.192 \\
\hline 4 & 5.7540 & 5.3566 & 174.67 & 32.149 & 193 & -1895.0 & -9.3530 & 761 & 8.5917 & 4.9869 & 10.828 & 13.375 & 1.196 \\
\hline 5 & 920 & 2557 & 186.54 & 1.123 & 3 & -2188.2 & -9.1229 & 880 & .5510 & 4.9500 & 10.840 & 13.618 & 1.620 \\
\hline 6 & 6.7920 & 5.9061 & 205.98 & 38.642 & 226 & -2337.6 & -9.1716 & 949 & 10.516 & 5.0131 & 10.945 & 13.680 & 11.548 \\
\hline 7 & 5.7709 & 5.2623 & 163.44 & 50.456 & 177 & -2039.2 & -9.5160 & & 8.5917 & 4.8269 & 10.778 & 13.577 & 1.340 \\
\hline 8 & 20 & 8500 & 100.07 & דוד & & -2039.1 & -9.1628 & tro & 8.5917 & & & & \\
\hline 9 & 540 & 5.3566 & 165.46 & 50.922 & 176 & -2039.2 & & 761 & 8.5917 & 4.8269 & & 13.439 & 11.239 \\
\hline 10 & 66647 & 6.2555 & 19759 & 55.256 & 219 & -2306.9 & -9.6973 & 986 & 10.516 & 4.9295 & 10.869 & 13.764 & 1.693 \\
\hline 11 & 0.0041 & 6.2555 & & 55.581 & & -2306.9 & & & & & & & \\
\hline 1 & 5.7540 & 5.3566 & 170.38 & 59.030 & 184 & -1923.2 & -8.7628 & 776 & 8.5917 & 4.9055 & 10.770 & 13.446 & 11.220 \\
\hline 13 & 5.7540 & 5.3566 & 177.54 & 61.099 & 107 & -2157.3 & -9.7346 & 776 & 8.5917 & 4.9024 & 10.769 & 13.395 & 13.395 \\
\hline 1 & & & & & & & & & & & & & \\
\hline 15 & 5.7540 & 5.3566 & 183.94 & 32.223 & 206 & -2018.4 & -9.1559 & 776 & 8.5917 & 4.9577 & 10.800 & 13.346 & 11.154 \\
\hline 10 & 6.6647 & 6.2555 & 180.89 & 69.597 & 201 & -2476.6 & -10.233 & 986 & 10.516 & 4.8182 & & 13.824 & 11.621 \\
\hline 11 & 6.6647 & 6.2555 & 181.20 & 69.924 & 200 & -2476.6 & -10.189 & 985 & 10.516 & 4.7924 & & 13.823 & 11.631 \\
\hline 18 & 6.2920 & 5.5257 & 171.48 & 32.161 & 190 & -2046.6 & -9.3665 & 880 & 9.5510 & 4.8896 & 10.802 & 13.611 & 11.403 \\
\hline 1 & 6.6647 & 6.2555 & 186.52 & 76.236 & 201 & -2451.6 & -9.8071 & & 10.516 & & & 13.799 & 13.799 \\
\hline 20 & 6.2920 & 5.5257 & 177.91 & 51.313 & 193 & -2009.5 & -9.8185 & 880 & 9.5510 & 4.8962 & 10.806 & 13.626 & 13.626 \\
\hline
\end{tabular}

The retention times were determined at three different temperatures within the linear range of the curve. The correlation coefficients of these curves are in the range of 0.9992 - 0.9998 in CBP5 and 0.9962 - 0.9991 in LM-1.

Some molecular descriptors values are given in Table 2.

According to the $r$ values, the molecular descriptors were classified in agreement with the method proposed by Dimov et al. ${ }^{3,4}$, into four groups depending on their individual significance for the retention studied. These groups are identified as follows: substantial, important, likely and specific.

In the present study, none of the available descriptors were enclosed in the group of the substantial and important ones, that is no $r$ was obtained above 0.80 . This classification is also shown in Table 3.

In the multiple linear regression, the contributors to the retention in agreement with the method proposed by Dimov et al. $^{3,4}$ were divided into two groups, basic and tuning:

$$
R I_{\text {calc }}=b_{0}+\sum_{i=1}^{n} b_{i} B_{i}+\sum_{j=n+1}^{n+k} b_{j} T_{j}
$$

where $R I_{\text {calc }}$ represents the calculated retention. The $B i$ parameters include those solute descriptors which allow the calculation of the $R I_{\text {calc }}$ value closest to the experimental retention ( $\left(\mathrm{RI}_{\exp }\right)$. The parameters $T_{j}$ are solute descriptors, which tune the $R I_{\text {calc }}$ value to that of $\mathrm{RI}_{\exp }$. Owing to the restriction of statistically-permitted intercorrelations, there is normally only one basic descriptor to be used. The problem is choice which basic descriptor forms the best combination with tuning contributor(s).

Different combinations of the variables representing each of two terms described above were tried to obtain the equation of best fit, which would relate the RI values of the reference compounds to their molecular structure. Multiple linear equations with two variables produced correlation coefficients with low values (the best was $r=0,8498$ with $\mathrm{A}_{\mathrm{T}}$ and $\mathrm{S}_{(-\mathrm{o}-)}$ in LM-1).

The series of compounds studied can be described by an equation comprising three types of terms: the size of the 
Table 3. Individual correlation coefficients, r, between coumarin retention indices obtained using two stationary phases with low polarities at $170{ }^{\circ} \mathrm{C}$ and corresponding descriptors.

\begin{tabular}{|c|c|c|c|}
\hline \multirow[t]{2}{*}{ Descriptors } & \multirow[t]{2}{*}{ Abbreviation } & \multicolumn{2}{|c|}{ Stationary Phase } \\
\hline & & LM-1 & CBP5 \\
\hline $\begin{array}{l}\text { Group of likely } \\
\text { parameters }\end{array}$ & \multicolumn{3}{|c|}{$(0.80>r>0.45)$} \\
\hline Wiener & $\mathrm{W}$ & 0.7327 & 0.7361 \\
\hline Kappa index & ${ }^{1} \mathrm{~K}$ & 0.7087 & 0.7097 \\
\hline \multirow{3}{*}{$\begin{array}{l}\text { Molecular connectivity } \\
\text { index }\end{array}$} & ${ }^{2} \mathrm{X}$ & 0.7166 & 0.7174 \\
\hline & ${ }^{3} X_{p}$ & 0.7061 & 0.7115 \\
\hline & ${ }^{5} \mathrm{X}_{\mathrm{p}}$ & 0.7561 & 0.7606 \\
\hline Polar Area & AP & 0.7119 & 0.7342 \\
\hline Total Energy & $\mathrm{E}_{\mathrm{T}}$ & -0.7487 & -0.7498 \\
\hline \multirow{4}{*}{$\begin{array}{l}\text { Topological state } \\
\text { index }\end{array}$} & $\mathrm{T}_{(-\mathrm{O}-)}$ & 0.7948 & 0.7945 \\
\hline & $\mathrm{T}_{(\mathrm{C} 2)}$ & 0.7618 & 0.7644 \\
\hline & $\mathrm{T}_{(\mathrm{C} 6)}$ & 0.7568 & 0.7717 \\
\hline & $\mathrm{T}_{(=\mathrm{O})}$ & 0.7006 & 0.7003 \\
\hline $\begin{array}{l}\text { Molecular connectivity } \\
\text { index }\end{array}$ & ${ }^{1} \mathrm{X}$ & 0.6873 & 0.6885 \\
\hline \multirow[t]{2}{*}{ Kappa index } & ${ }^{2} \mathrm{~K}$ & 0.6199 & 0.6201 \\
\hline & ${ }^{3} \mathrm{~K}$ & 0.6797 & 0.6776 \\
\hline \multirow{4}{*}{$\begin{array}{l}\text { Molecular connectivity } \\
\text { index }\end{array}$} & ${ }^{4} X_{p}$ & 0.6912 & 0.6857 \\
\hline & ${ }^{4} \mathrm{X}_{\mathrm{pc}}$ & 0.6928 & 0.6971 \\
\hline & ${ }^{3} \mathrm{X}_{\mathrm{c}}$ & 0.7061 & 0.7115 \\
\hline & ${ }^{6} X_{p}$ & 0.6873 & 0.6865 \\
\hline Total Area & $\mathrm{A}_{\mathrm{T}}$ & 0.5806 & 0.5614 \\
\hline Molar Refractivity & MR & 0.5578 & \\
\hline Volume Molecular & $\mathrm{V}_{\mathrm{M}}$ & 0.4629 & 0.4500 \\
\hline Volume Molar & $\mathrm{V}_{\text {Molar }}$ & 0.4521 & 0.4188 \\
\hline $\begin{array}{l}\text { Group of specific } \\
\text { parameters }\end{array}$ & $(\mathrm{r}<0.45)$ & & \\
\hline \multirow{2}{*}{$\begin{array}{l}\text { Electrotopological state } \\
\text { index }\end{array}$} & $\mathrm{S}_{(-\mathrm{O}-)}$ & -0.4081 & -0.4362 \\
\hline & $\mathrm{S}_{(=\mathrm{O})}$ & 0.3187 & 0.2940 \\
\hline \multirow{7}{*}{$\begin{array}{l}\text { Molecular connectivity } \\
\text { index }\end{array}$} & ${ }^{1} \mathrm{X}^{\mathrm{v}}$ & 0.4033 & 0.3840 \\
\hline & ${ }^{4} \mathrm{X}_{\mathrm{pc}}{ }^{\mathrm{v}}$ & 0.3659 & 0.3553 \\
\hline & ${ }^{3} \mathrm{X}_{\mathrm{p}}^{\mathrm{v}}$ & 0.3178 & 0.3046 \\
\hline & ${ }^{2} X^{v}$ & 0.3169 & 0.3069 \\
\hline & ${ }^{3} \mathrm{X}_{\mathrm{c}}^{\mathrm{v}}$ & 0.2258 & 0.2183 \\
\hline & ${ }^{4} \mathrm{X}_{\mathrm{p}}^{\mathrm{v}}$ & 0.2018 & 0.1866 \\
\hline & ${ }^{5} \mathrm{X}_{\mathrm{p}}^{\mathrm{v}}$ & 0.1459 & 0.1349 \\
\hline Saturated area & $\mathrm{A}_{\mathrm{S}}$ & -0.2244 & 0.3498 \\
\hline Unsaturated area & $A_{\text {UNS }}$ & -0.2220 & 0.3193 \\
\hline HOMO energy & $\mathrm{E}_{\mathrm{HOMO}}$ & -0.0812 & -0.1123 \\
\hline
\end{tabular}

molecule, and the topological and electronic factors. The best equations were obtained with $\mathrm{A}_{\mathrm{T}},{ }^{1} \mathrm{~K}, \mathrm{~W},{ }^{3} \mathrm{X}_{\mathrm{p}}$ and $\mathrm{V}_{\mathrm{M}}$ as the first term of the equation (basic descriptors), reflecting the bulk properties of the molecule. These basic descriptors have high colinearity to each other. However, only one of them was used in each equation. The second and third terms (tuning descriptors) were represented by $\mathrm{S}_{(-\mathrm{o}-)}$ related with the topological and electronic factors and $\mathrm{E}_{\text {HOMO }}$ related with the ionisation potential of the molecule. The colinearities between them were also checked.

The best multiple linear regression Eqs. 2 - 3 with three variables with LM-1 and CBP5 stationary phases $\left(170^{\circ} \mathrm{C}\right)$ were:

$$
\begin{aligned}
& \mathrm{I}_{\mathrm{LM}-1\left(170{ }^{\circ} \mathrm{C}\right)}=9.474( \pm 0.815) A_{T}+220.2 \\
& ( \pm 32.2) E_{\text {номо }}-2013( \pm 192) S_{(-O-)}+11957( \pm 1081) \\
& \mathrm{n}=20 \quad \mathrm{r}=0.9561 \quad \mathrm{~s}=41.90 \\
& \text { F-ratio }=56.74 \quad r_{c v}^{2}=0.8573 \\
& \text { (F-to-remove: } 4.00) \quad \mathrm{F}\left(A_{T}\right)=135.1 \\
& \mathrm{~F}\left(E_{\text {Номо }}\right)=46.79 \quad \mathrm{~F}\left(S_{\left(-O_{-}\right)}\right)=109.4 \\
& \mathrm{I}_{\mathrm{CBP} 5\left(170{ }^{\circ} \mathrm{C}\right)}=10.07( \pm 0.95) A_{T}+233.8( \pm 37.3) E_{\text {HOMO }}- \\
& 2271( \pm 223) S_{(-O-)}+13319( \pm 1254) \\
& \mathrm{n}=20 \quad \mathrm{r}=0.9507 \quad \mathrm{~s}=48.61 \\
& \text { F-ratio }=50.16 \quad \mathrm{r}_{\mathrm{cv}}^{2}=0.8265 \\
& \text { (F-to-remove: 4.00) } \mathrm{F}\left(A_{T}\right)=113.3 \\
& \mathrm{~F}\left(E_{\text {НОМо }}\right)=39.22 \quad \mathrm{~F}\left(S_{\left(-O_{-}\right)}\right)=103.5
\end{aligned}
$$

The best simple regressions were obtained with descriptors related to the shape, size, area, volume and molecular refractivity of the substance studied. In the multiple linear regression the electronic descriptors were introduced.

The total area was the first parameters introduced into the multiple linear equations as it was found to be the most significant (see the values of F, Eqs. 2-3). The positive sign of the coefficient in the Eqs. 2-3 indicates that retention indices increase with the total area values as is observed in Table 2. The second parameter introduced in the equations (the second most significant according to the values for $\mathrm{F}$, Eqs. 2 and 3) was the electrotopological index ( $\mathrm{Si}$ ) related to the oxygen atom in the position 1 of the coumarins. The nature of the substituents in the molecule influences this index. Substituents with electron-donating effect contribute to increase the value of the index and those with electron-withdrawing effect decrease it. The negative sign of the coefficient in Eqs. 2 and 3 indicates that retention indices increase as the electrotopologic indices $\left(\mathrm{S}_{-\mathrm{o}-}\right)$ in the molecule decrease. In agreement with the experimental retention indices, it can be observed that in a general way, compounds with more electronegative substituents have larger retention values.

The third parameter introduced in the multiple regression equations according to its significance (see the values of $\mathrm{F}$ in the Eqs. 2 and 3) was the energy of the highest occupied molecular orbital of the solute, $\mathrm{E}_{\text {Hомо }}$. The intro- 
Table 4. Experimental and calculated retention indices (RI and $\mathrm{RI}$ calc) determined on $\mathrm{LM}-1$ and $\mathrm{CBP} 5$ stationary phases at $170{ }^{\circ} \mathrm{C}$ and its residual, $\Delta$ ( $\mathrm{RI}$ $-\mathrm{RI}_{\mathrm{calc}}$ ) and standardized residual, $\mathrm{S}_{\mathrm{R}}$, of Eqs. 2 and 3 for the coumarins used in this study.

\begin{tabular}{llcccccccc}
\hline No. & Compound & RI LM-1 & $\begin{array}{c}\mathrm{RI}_{\text {calc }} \\
\text { (Eq. 2) }\end{array}$ & $\begin{array}{c}\Delta \\
\text { (Eq. 2) }\end{array}$ & $\begin{array}{c}\mathrm{S}_{\mathrm{R}} \\
\text { (Eq. 2) }\end{array}$ & RICBP5 & $\begin{array}{c}\mathrm{RI}_{\text {calc }} \\
\text { (Eq. 3) }\end{array}$ & $\begin{array}{c}\Delta \\
\text { (Eq. 3) }\end{array}$ & $\begin{array}{c}\mathrm{S}_{\mathrm{R}} \\
\text { (Eq. 3) }\end{array}$ \\
\hline 1 & Coumarin & 1434 & 1460 & -26 & -0.70 & 1492 & 1517 & -25 & -0.59 \\
2 & 3,4-Dihydrocoumarin & 1398 & 1345 & 54 & 1.82 & 1451 & 1383 & 68 & 2.02 \\
3 & 6-Methylcoumarin & 1545 & 1568 & -23 & -0.56 & 1588 & 1625 & -37 & -0.79 \\
4 & 7-Methylcoumarin & 1545 & 1516 & 29 & 0.75 & 1586 & 1566 & 20 & 0.43 \\
5 & 6-Methoxycoumarin & 1762 & 1753 & 8 & 0.21 & 1835 & 1823 & 12 & 0.25 \\
6 & 7-Ethoxycoumarin & 1754 & 1800 & -46 & -1.44 & 1815 & 1864 & -49 & -1.32 \\
7 & 4-Hydroxycoumarin & 1656 & 1696 & -40 & -1.04 & 1740 & 1778 & -38 & -0.86 \\
8 & 6-Hydroxycoumarin & 1760 & 1750 & 10 & 0.26 & 1840 & 1833 & 7 & 0.15 \\
9 & 7-Hydroxycoumarin & 1789 & 1779 & 10 & 0.27 & 1866 & 1867 & -1 & -0.02 \\
10 & 6-Acetocoumarin & 1768 & 1773 & -5 & -0.12 & 1846 & 1847 & -1 & -0.02 \\
11 & 7-Acetocoumarin & 1779 & 1782 & -3 & -0.07 & 1851 & 1854 & -3 & -0.07 \\
12 & 6-Aminocoumarin & 1784 & 1769 & 15 & 0.42 & 1872 & 1846 & 26 & 0.64 \\
13 & 6-Chlorocoumarin & 1578 & 1629 & -51 & -1.31 & 1639 & 1698 & -59 & -1.29 \\
14 & 7-Chlorocoumarin & 1586 & 1642 & -56 & -1.43 & 1643 & 1712 & -69 & -1.51 \\
15 & 6-Iodocoumarin & 1780 & 1706 & 74 & 2.06 & 1859 & 1772 & 87 & 2.10 \\
16 & 6-Nitrocoumarin & 1775 & 1721 & 54 & 1.61 & 1875 & 1806 & 69 & 1.79 \\
17 & 7-Nitrocoumarin & 1784 & 1785 & -1 & -0.03 & 1877 & 1878 & -1 & -0.03 \\
18 & 6-Formylcoumarin & 1673 & 1679 & -6 & -0.14 & 1759 & 1752 & 7 & 0.14 \\
19 & 6-Carboxycoumarin & 1858 & 1808 & 50 & 1.32 & 1942 & 1895 & 47 & 1.05 \\
20 & 6-Cyanocoumarin & 1579 & 1627 & -48 & -1.22 & 1638 & 1696 & -58 & -1.29 \\
\hline
\end{tabular}

duction of this parameter, that is less significant, resulted in an increase of the multiple correlation coefficients (r). $\mathrm{E}_{\mathrm{HOMO}}$ is related to the energy necessary to remove an electron from a molecule. The sign of the coefficient in the Eqs. 2-3 is positive, thus the negative values of Еномо that correspond to more electron-donating molecules, contribute to decrease the chromatographic retention. This is, in accordance with the value of $\mathrm{S}_{(-\mathrm{o}-)}$, thus $\mathrm{E}_{\text {Hомо }}$ should correct the values of $\mathrm{S}_{(-\mathrm{o}-)}$, considering that $\mathrm{E}_{\text {номо }}$ is a molecule global value and not localised in an atom as $\mathrm{S}_{(-\mathrm{o}-\mathrm{-})}$.

The validation of the model was checked through the values of $r^{2}$ cv (coefficient of validation of the capacity of prediction of the model) which was better for the Eqs. 2 and 3 , where the total area was the most significant parameter.

The calculated retention indices with the Eqs. 2 and 3, residuals and standard residuals are given in Table 4.

The correlation between experimental retention indices (LM-1 and CBP5) and those calculated by Eqs. 2 and 3 is shown in Fig. 1.

It is observed in Fig. 1 that two points corresponding to compounds 2 and 15 (Table 4) exhibit a significantly large $s$. When the correlation is made without these outliers the correlation coefficient is improved, $\mathrm{r}=0.9647$ for the $\mathrm{I}_{\mathrm{LM}-1}$ and $\mathrm{r}=0.9642$ for $\mathrm{I}_{\mathrm{CBP} 5}$.

The interactions between the molecules of the solute and those of the two stationary phases used in this work are similar. These are observed by the simple linear correlations obtained between the experimental retention indices (or calculated) of the two stationary phases, whose correlation coefficient is excellent.

$$
\begin{array}{ll}
\mathbf{I}_{\mathbf{C B P 5}}=1.094 & ( \pm 0.040)) \\
\mathrm{n}=20 & \mathbf{I}_{\text {LM-1 }}-86.25( \pm 69.16) \\
\underline{\mathrm{F}}=3132.42 & \mathrm{r}=0.9971 \quad \mathrm{r}=11.17 \\
\underline{\mathrm{r}} \mathrm{cv}=0.9930
\end{array}
$$

The angular coefficient of this Eq. 4 demonstrates that there is not appreciable discrimination between the phases. However, the intercept shows that the values of $\mathrm{I}_{\mathrm{CBP} 5}$ are smaller than that of $\mathrm{I}_{\mathrm{LM}-1}$. This fact could be explained by different diffusion rates in the stationary phases or other dynamic factors. 

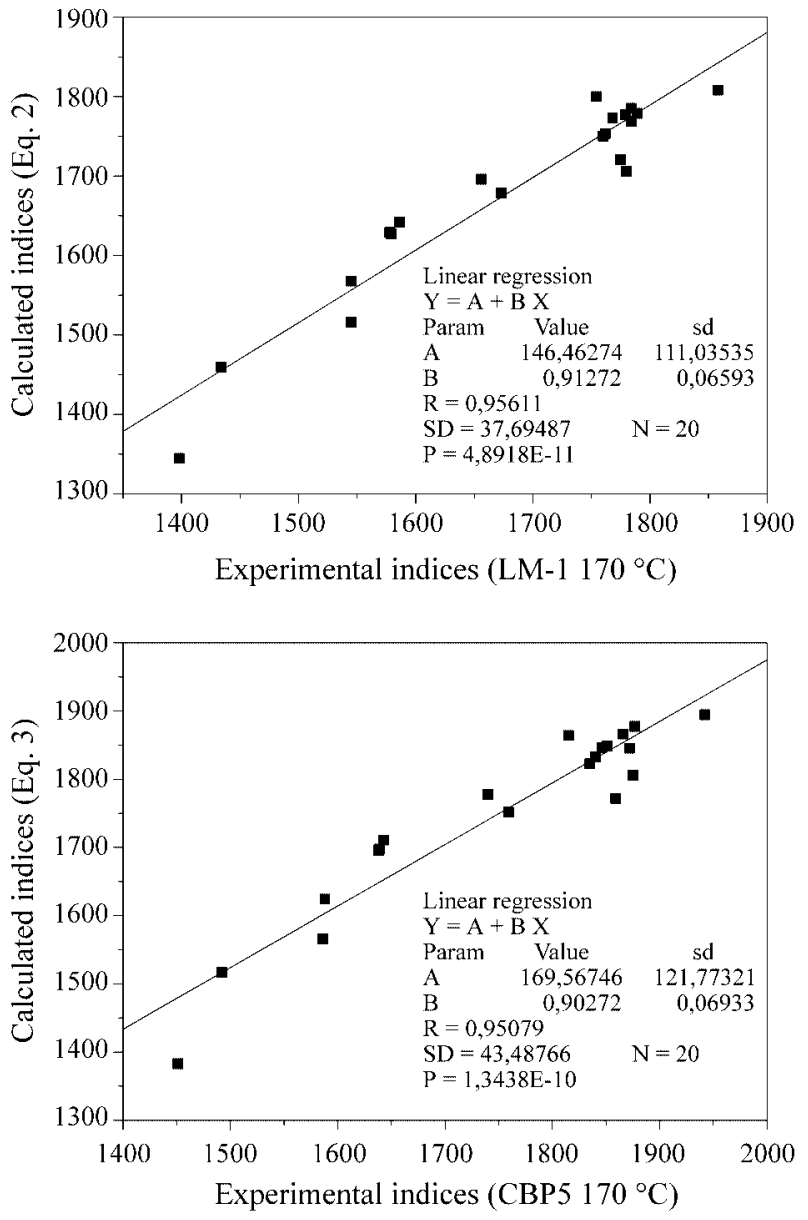

Figure 1. Correlation between experimental indices (LM-1 and CBP5) and calculated retention indices (Eqs. 2 and 3 ) for the coumarins used in this study.

\section{Conclusions}

This study demonstrates that the methodology used previously by Dimov to model GC retention characteristics of the hydrocarbons (alkylbenzenes, alkylnaphthalenes, isoalkanes and alkenes) can also be applied to model the retention indices of substituted coumarins, although the correlations were not as good as the first ones.

The descriptors that are able to describe the phenomena that took place in the process of the retention of the studied compounds are related with the shape and the electronic characteristics of the molecules.

The models found have good predictive ability as established by cross-validation $r^{2}{ }_{c v}$ values and thus can be used to help in the elucidation of molecular structures or prediction of chromatographic retention indices of similar compounds.

\section{Acknowledgement}

The authors thank CNPq (Brazil) for financial support.

\section{References}

1. Kaliszan R. Quantitative Structure-chromatographic Retention Relationships; John Wiley \& Sons; New York, 1987.

2. Sutter, J.M.; Peterson, T.A.; Jurs, P.C. Anal. Chim. Acta 1997, 342, 113.

3. Dimov, N.; Osman, A. Anal. Chim. Acta 1996, 323, 15.

4. Dimov, N.; Osman, A.; Mekenyan, Ov.; Papazova, D. Anal. Chim. Acta 1994, 298, 303.

5. Heinzen, V.E.F.; Yunes, R.A. J. Chromatogr. 1992, $598,243$.

6. Heinzen, V.E.F.; Yunes, R.A. J. Chromatogr. 1993, $654,83$.

7. Arruda, A.C.; Heinzen, V.E.F.; Yunes, R.A. J. Chromatogr. 1993, 630, 251.

8. Heinzen, V.E.F.; Yunes, R.A. J. Chromatogr. A 1996, $719,462$.

9. Salabert-Salvador, M.T.; Garcia-March, F.J.;PérezGiménez F. et al. Chromatographia 1995, 41, 702.

10. Righezza, M.; Hassani, A.; Meklati, B.Y.; Chrétien, J.R. J. Chromatogr. A 1996, 723, 77.

11. Garcia-March, F.J.; Antón-Fos, G.M.; PérezGiménez, F.; Salabert-Salvador, M.T.; Cercós-delPozo, R.A.; Julian-Ortiz, J.V. J. Chromatogr.A 1996, $719,45$.

12.Zhang, X.; Lu, P. J. Chromatogr. A 1996, 731, 187.

13. Peng, C.T. J. Chromatogr. A 1994, 687, 189.

14. Li, J.; Carr, P.W. J. Chromatogr. A 1994, 659, 367.

15. Hilal, S.H.; Carreira, L.A. J. Chromatogr. A 1994, $662,269$.

16. Kalliszan, R. Anal. Chem. 1992, 64, 619A.

17. Mihalic, Z.; Trinajstic, N. J. Chem. Educ. 1992, 69, 701.

18. Kier, L.B. In Physical Chemical Properties of Drugs, Yalkowsky, S.H.; Sinkula, A.; Valvani, S.C., eds., Marcel Dekker; N. Y., Ch. 9, p. 277, 1980.

19. Hansch, H; Leo, A. Exploring QSAR. Fundamentals and Applications in Chemistry and Biology; Washington, ACS, 1995.

20. Santos, H.F.; Almeida, W.B. J. Molec. Struct. 1995, $335,129$.

21. Sharples, W.E.; Vermon, F. J. Chromatogr. 1978, $161,83$.

22. Tarjan, G.; Nyiredy, Sz.; Gyor, M. et al. J. Chromatogr. 1989, 472, 1.

23. Wiener, H. J. Am. Chem. Soc. 1947, 69, 17 and 2636.

24. Kier, L.B.; Hall, L.H. Molecular Connectivity in Structure-Activity Analysis; Wiley; New York, 1986.

25. Kier, L.B. Quant. Struct.-Act. Relat. 1987, 6, 8.

26. Kier, L.B.; Hall, L.H. Pharm. Res. 1990, 7, 801.

27. Hall, L.H.; Mohney, B.; Kier, L.B. J. Chem. Inf. Comput. Sci. 1991, 31, 76. 
28. Hall, L.H.; Kier, L.B. Quant. Strut.-Act. Relat. 1990, 9, 115.

29. Hall, L.H.; Kier, L.B. Molconn-X, a Program for Molecular Topology Analysis; User's Guide. 1. ed. Quincy; Massachusetts, 1991.

30. Stewart, J.J.P. MOPAC, version 6.0, J. Seiler Research Laboratory, US Air Force Academy, Colorado Springs. CO80840-6528, USA, 1990.
31. Makovskaya, V.; Dean, J.R.; Tomlinson, W.R.; Comber, M. Anal. Chim. Acta 1995, 315, 193.

32. Muresan, S.; Bologa, C.; Mracec, M.; Chiriac, A.; Jastorff, B.; Simon, Z.; Naráy-Szabó, G. J. Molec. Struct. 1995, 42, 161.

33. Wagener, M.; Sadowski, J.; Gasteiger, J. J. Am. Chem. Soc. 1995, 117, 7769. 
28. Hall, L.H.; Kier, L.B. Quant. Strut.-Act. Relat. 1990, 9, 115.

29. Hall, L.H.; Kier, L.B. Molconn-X, a Program for Molecular Topology Analysis; User's Guide. 1. ed. Quincy; Massachusetts, 1991.

30. Stewart, J.J.P. MOPAC, version 6.0, J. Seiler Research Laboratory, US Air Force Academy, Colorado Springs. CO80840-6528, USA, 1990.
31. Makovskaya, V.; Dean, J.R.; Tomlinson, W.R.; Comber, M. Anal. Chim. Acta 1995, 315, 193.

32. Muresan, S.; Bologa, C.; Mracec, M.; Chiriac, A.; Jastorff, B.; Simon, Z.; Naráy-Szabó, G. J. Molec. Struct. 1995, 42, 161.

33. Wagener, M.; Sadowski, J.; Gasteiger, J. J. Am. Chem. Soc. 1995, 117, 7769. 